\title{
Technology in Accounting Classrooms: An Assessment Of The Current State
}

\author{
Kathy H. Y. Hsu (kathy@louisiana.edu), University of Louisiana at Lafayette \\ John Tanner (jrt4671@louisiana.edu), University of Louisiana at Lafayette \\ Mike Cudd, Mississippi College \\ Nina Guildry, University of Louisiana at Lafayette
}

\begin{abstract}
As technology evolution continue to reduce the costs associated with hardware and software for classroom instructions, the instructional environment and teaching pedagogy of business faculty in many disciplines also have evolved over time. While technology integration in accounting education has been a constant focal point of discussion in recent years, the extant and the usage pattern of various classroom technologies in accounting instructions is unclear. This paper provides an assessment of technology usage in today's accounting classroom.
\end{abstract}

\section{Introduction}

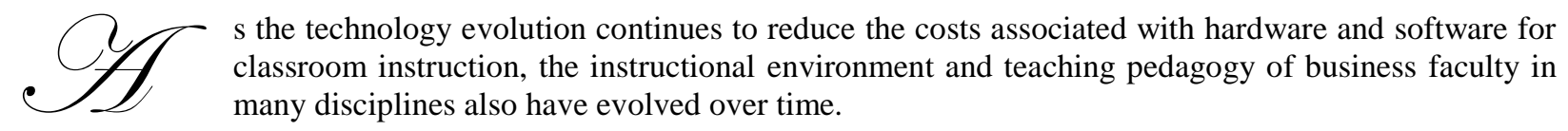

While the intangible cost of faculty time spent in changing teaching pedagogy to incorporate new classroom technology is often cited as prohibiting factor for the wide-spread usage of available instructional technology in accounting, the necessity of modernizing accounting instruction to bridge the widening gap between technologies used in accounting practice today and the technologies to which accounting students are exposed to in university accounting programs is well-recognized. In a report by the AICPA Accounting Change Commission published in 1993 (Williams, 1993), integration of technology into accounting curriculum was listed as one of the primary areas need to be addressed in accounting education. In 1998, the Education Committee of the International Federation of Accountants (IFAC) also issued an International Education Guideline (IEG 11) to address the issues of incorporating information technology in the accounting curriculum. As rapid technology developments continue to place high demands on accounting professionals to update their skills set, accounting educators also are under pressure to modernize and to maintain the relevancy of their classes.

This study surveyed accounting faculty throughout the United States to create a profile of today's classroom technology usage in accounting. Specifically, we are interested in knowing the extent to which today's accounting classroom has moved from the pure "chalk and talk" to the use of audiovisual equipments such as movie, filmstrip, video tapes, overhead transparencies, computer and the Internet. While the specific methods used and the extent of technology integration into individual accounting courses is beyond the scope of this current study, we attempt to shed light on the rudimentary issue of technology integration into accounting curriculum-the hardware and software usage profile in today's accounting classroom.

\section{Literature Review}

Educational technology (ET) research has extensively examined the value of various technologies used in instructional settings. While the explicit costs of technology and the implicit costs of faculty resources spent on incorporating technology into teaching pedagogy often generates extensive debates on the cost-benefit of classroom technology, many studies have provided evidence demonstrating the enrichment value of various classroom technologies. For example, in the area of computer-assisted learning, Schwartz et al. (1999) report that the 
integration of intelligent tutorial software helped students to apply what they had learned in one setting to a new setting. Ragan et al. (1993) reported that multimedia instruction is at least as effective as conventional forms and has substantial cost benefits and efficiency. The use of Internet access to detailed lecture notes and examples, tutorials and other instructional support materials also have been proven to increase student motivation due to their active involvement in the learning process (Gilliver et al., 1998).

Prior studies in accounting education also show that there is merit in using computer-based instruction (CBI) tutorials in accounting education via computer network to enhance student learning (Rowley and Layne, 1990) and that intranet is an effective tool to facilitate student learning (Lont, 1999). However, a recent survey by Basile and D'Aquila (2000) of accounting students revealed no significant differences between the general attitudes of students exposed to WebCT versus traditional instruction in principles of accounting courses.

As the debate and research of the benefits of classroom technology in accounting instruction continues, new and more user-friendly technologies are being developed which will continue to reduce the overall costs of incorporating new technology into accounting classrooms. As this transition takes place, it is important to establish a baseline of the current teaching practices that employ technology in accounting instruction in order to determine in the future the extent to which technology has been further incorporated in accounting pedagogy. Establishing this baseline is the primary focus of this study.

\section{Methodology}

A random sample of 1000 accounting faculty members was taken from Dr. James Hasselback's Accounting Faculty database. A mail questionnaire was sent to each faculty member selected A total of 261 usable responses were returned, for a response rate of 26.1 percent, which is considered to be within acceptable limits (Alreck and Settle, 1985).

The questionnaire used in this study is a replica of the one used in a previous study of finance faculty (Cudd, Lipscomb, and Tanner, 2003). It contained four sections that address usage of various types of classroom hardware, software usage, distance education activity, and respondent demographics, respectively.

\section{Results And Analysis}

\section{Respondent Demographics}

The demographic characteristics of the respondents are displayed in Table 1. More than 63 percent were teaching at state universities, with 36.2 percent teaching at private universities. Respondents were relatively evenly distributed with respect to university size, with more than 25 percent at universities with more than 20,000 students, and only 11.3 percent at universities with 15,000 to 20,000 students. Additionally, almost three-fourths of the respondents were at AACSB-accredited universities. Exactly 73 percent of the respondents taught in colleges of business with enrollments exceeding one thousand students. Respondents were relatively evenly divided among the ranks of full, associate, and assistant professor (27.6 percent, 35.2 percent, and 33.6 percent, respectively), with only more than 3 percent instructors or lecturers. More than two-thirds of the respondents were males, and 86 percent of the respondents had ten years or more college teaching experience. Consequently, the sample is representative of a broad diversity of accounting faculty with regard to the above demographic variables. 
Table 1: Demographic Characteristics of Respondents

\begin{tabular}{llcc}
\hline Sample Demographics & & $\mathbf{n}$ & $\mathbf{\%}$ \\
\hline \multirow{3}{*}{ Type of University } & & & \\
& State & 164 & $63.8 \%$ \\
& Private & 93 & $36.2 \%$ \\
\hline University Enrollment & Less than 5000 & $25.0 \%$ \\
& $5001-10000$ & $22.3 \%$ & $15.6 \%$ \\
& $10001-15000$ & 57 & $11.3 \%$ \\
\hline AACSB Accreditation & $15001-20000$ & 40 & $25.8 \%$ \\
& More than 20000 & $73.9 \%$ \\
& Accredited & 29 & $26.1 \%$ \\
\hline College Enrollment & Not accredited & 66 & $26.9 \%$ \\
& $\leq 1000$ & 190 & $36.1 \%$ \\
& $1001-2000.1$ & 67 & $36.9 \%$ \\
\hline Academic Rank & Over 2000 & 67 & $27.6 \%$ \\
& Assistant professor & 90 & $35.2 \%$ \\
& Associate professor & 92 & $33.6 \%$ \\
& Full professor & 69 & $3.6 \%$ \\
\hline Gender & Instructor/Lecturer & 88 & $67.6 \%$ \\
& Male & 84 & $32.4 \%$ \\
\hline Years Teaching & Female & 9 & $17.0 \%$ \\
& $1-5$ years & 83 & $13.6 \%$ \\
& $6-10$ & 36 & $19.1 \%$ \\
& $11-15$ & 35 & $16.3 \%$ \\
& $16-20$ & 49 & $37.0 \%$ \\
\hline
\end{tabular}

\section{Classroom Hardware Usage in Accounting Instruction}

Table 2 shows the percentage of usage of the various types of classroom hardware in accounting instruction. The overhead transparency projector is a common classroom hardware device used by 71.5 percent of the respondents, with more than one-third of the respondents stating that they employed transparencies in more than $40 \%$ of their class meetings. Transparencies have long been used in many classrooms, and the inexpensive and nontechnical nature of transparencies likely contributes to their significant usage.

However, videocassette recorder (VCR) usage was moderate, with only 42.1 percent of the respondents saying that they used VCRs in the classroom, and the usage rate within that group was very low, with less than 2 percent of the faculty using VCRs in more than 20 percent of the class meetings. The low VCR usage is not surprising since many accounting classes are quantitative to one degree or another and, consequently, less suitable to taped video presentations than more qualitative subject areas.

A similar finding and argument are true for camcorder and digital camera usage. Only 8.3 percent of the respondents indicate any usage of camcorders and digital cameras, and less than $1 \%$ indicated using such devices in more than 20 percent of the class meetings.

The extensive shift in accounting instruction to the use of computer image projection is evidenced by the extremely high percentage of accounting faculty that employed some variation of this type of device (i.e., frontorientation, rear-orientation, or wall-mounted). Over 82 percent of the respondents employed front-orientation computer projection systems, and 50 percent used the systems in more than 20 percent of class meetings.

Front-orientation computer projection systems are the less expensive method of providing computer image projection, and typically involve no more than a computer and projector mounted on a cart for a total cost of roughly $\$ 3,000-4,000$. More expensive computer projection system alternatives include rear-orientation systems resembling 
free standing, over-sized television sets, and wall-mounted plasma display panels that resemble thin-line television sets. These devices often provide digital chalkboard capabilities that enable the instructor to write electronically directly on the image, as well as slightly better imagery. Their excessive costs, which fall in the $\$ 15,000$-to- $\$ 25,000$ range, contributes to their scarcity and the subsequent low rates of faculty usage indicated in the survey. Only 12.6 percent of the responding faculty reported any usage of rear-orientation computer projection systems, and less than 2 percent employed wall-mounted plasma display units.

Digital image capture systems (also known as document cameras or "Elmos") function as closed-circuit television cameras and bear a physical resemblance to an overhead transparency projector. Unlike overhead transparency projectors that simply project a visual image through a magnifying lens, digital image capture systems electronically scan the image, convert it to digital form, and then project it to a viewing screen. This process enables the instructor to simply place a newspaper or book under the camera to project an enlarged image electronically. A digital image document camera is typically included as an adjunct to an existing front-orientation projection cart. The relatively high cost of this item as an auxiliary device, roughly $\$ 1,000-2,500$, contributes to its scarcity. The simplicity of use, however, makes it attractive to less technologically oriented faculty. Survey responses indicate that slightly less than 22 percent of the respondents used digital image capture systems, and more than 11 percent of the responding faculty use such systems in more than 20 percent of the class meetings. The greater availability of digital images that may be captured via the Internet today may also contribute the low usage of digital image capture systems by accounting faculty.

Table 2: Hardware Usage

\begin{tabular}{|c|c|c|c|c|c|c|}
\hline $\begin{array}{l}\begin{array}{l}\text { Hard ware } \\
(n=261)\end{array} \\
\end{array}$ & $\begin{array}{l}0 \% \text { of } \\
\text { the time }\end{array}$ & $\begin{array}{c}1-20 \% \text { of } \\
\text { the time }\end{array}$ & $\begin{array}{c}21-40 \% \text { of } \\
\text { the time }\end{array}$ & $\begin{array}{l}41-60 \% \text { of } \\
\text { the time }\end{array}$ & $\begin{array}{c}61-80 \% \text { of } \\
\text { the time }\end{array}$ & $\begin{array}{c}\text { more than } 80 \% \\
\text { of the time }\end{array}$ \\
\hline Transparencies & $28.5 \%$ & $38.1 \%$ & $11.9 \%$ & $7.7 \%$ & $6.9 \%$ & $6.9 \%$ \\
\hline VCRs & $57.9 \%$ & $40.9 \%$ & $1.1 \%$ & $0.0 \%$ & $0.0 \%$ & $0.0 \%$ \\
\hline $\begin{array}{l}\text { Camcorders/ } \\
\text { Digital Cameras }\end{array}$ & $91.7 \%$ & $7.9 \%$ & $0.4 \%$ & $0.0 \%$ & $0.0 \%$ & $0.0 \%$ \\
\hline $\begin{array}{l}\text { Front-orientation } \\
\text { Computer } \\
\text { Projection } \\
\text { Systems }\end{array}$ & $17.4 \%$ & $13.2 \%$ & $11.2 \%$ & $32.6 \%$ & $10.1 \%$ & $15.5 \%$ \\
\hline $\begin{array}{l}\text { Rear-orientation } \\
\text { Computer } \\
\text { Projection } \\
\text { Systems }\end{array}$ & $87.3 \%$ & $5.5 \%$ & $2.8 \%$ & $2.4 \%$ & $1.2 \%$ & $0.8 \%$ \\
\hline $\begin{array}{l}\text { Wall-mounted } \\
\text { Plasma } \\
\text { Display Panels } \\
\end{array}$ & $98.4 \%$ & $1.6 \%$ & $0.0 \%$ & $0.0 \%$ & $0.0 \%$ & $0.0 \%$ \\
\hline $\begin{array}{l}\text { Digital Image } \\
\text { Capture } \\
\text { Systems } \\
\end{array}$ & $78.2 \%$ & $9.9 \%$ & $3.2 \%$ & $5.5 \%$ & $2.4 \%$ & $0.8 \%$ \\
\hline $\begin{array}{l}\text { Networked } \\
\text { Computer } \\
\text { Labs }\end{array}$ & $57.0 \%$ & $26.6 \%$ & $6.7 \%$ & $3.1 \%$ & $3.1 \%$ & $3.5 \%$ \\
\hline
\end{tabular}

Networked computer labs permit the instructor to guide students through spreadsheets designed for specific accounting problems and cases, as well as other coordinated in-class activities requiring computer access. Less than half of the respondents provided some instruction in networked computer labs, but the bulk of the usage involves no more than $20 \%$ of the semester class meetings. Most computer labs are generic with standard spreadsheet software, rather than being specifically dedicated to use by accounting classes, which enhances their availability. Consequently, the use of computer labs for accounting instruction is largely driven by faculty need. 


\section{Classroom Software Usage in Accounting Instruction}

Table 3 provides usage data for the various types of software used in accounting classes by the respondents. More than 78 percent of the responding faculty use computer presentation software (e.g., PowerPoint), which is consistent with the high usage of computer presentation hardware noted earlier. More than 38 percent of the faculty used presentation software the minimum number of class meetings, and slightly less than 12 percent of the faculty using it the maximum number of class meetings. ${ }^{1}$ The use of presentation software is especially beneficial in quantitative courses involving graphs and tables, such as accounting. Students typically come to class with advanced hard copies of the presentation slides, which permits student attention to be directed to the instructor's lecture, rather than focusing on copying down the projected images. Textbook publishers have also fueled the popularity of presentation software by supplying author-written presentation software for many textbooks.

Spreadsheet analysis is one of the primary tools used in the field of accounting, so the high percentage of almost 78 percent of responding faculty using spreadsheet software is expected. Publishers also commonly provide student disks with spreadsheet templates for cases and problems. Spreadsheets (e.g., Excel), however, are primarily used for application purposes, rather than introduction to accounting theory. Consequently, the most common usage rate, which was greater than 52 percent, occurs in 20 percent or less of the respondents' classes.

Database management software (e.g., Access) is most pertinent to accounting systems courses, which are relatively scarce in number. It is not surprising, therefore, that a small portion which included only 13.5 percent of the accounting faculty respondents use database management software, and an even smaller percentage, which included only 4 percent of the respondents, use it for more than 20 percent of the class meetings.

Table 3: Software Usage

\begin{tabular}{lcccccc}
\hline $\begin{array}{l}\text { Software Type } \\
(\mathbf{n = 2 6 1 )}\end{array}$ & $\begin{array}{c}\mathbf{0 \%} \text { of } \\
\text { the time }\end{array}$ & $\begin{array}{c}\mathbf{1 - 2 0 \%} \text { of } \\
\text { the time }\end{array}$ & $\begin{array}{c}\mathbf{2 1 - 4 0 \%} \text { of } \\
\text { the time }\end{array}$ & $\begin{array}{c}\mathbf{4 1 - 6 0 \%} \text { of } \\
\text { the time }\end{array}$ & $\begin{array}{c}\mathbf{6 1 - 8 0 \%} \text { of } \\
\text { the time }\end{array}$ & $\begin{array}{c}\text { more than 80\% } \\
\text { of the time }\end{array}$ \\
\hline $\begin{array}{l}\text { Computer } \\
\begin{array}{l}\text { Presentation } \\
\text { Software }\end{array}\end{array}$ & $21.2 \%$ & $38.6 \%$ & $10.4 \%$ & $8.9 \%$ & $9.3 \%$ & $11.6 \%$ \\
$\begin{array}{l}\text { Spreadsheet } \\
\text { Software }\end{array}$ & $22.4 \%$ & $52.5 \%$ & $13.5 \%$ & $4.3 \%$ & $4.2 \%$ & $3.1 \%$ \\
\hline $\begin{array}{l}\text { Database } \\
\text { Management } \\
\text { Software }\end{array}$ & $86.4 \%$ & $9.6 \%$ & $2.0 \%$ & $0.8 \%$ & $0.8 \%$ & $0.4 \%$ \\
\hline
\end{tabular}

\section{Distance Education Activity in Accounting Instruction}

Some universities are dedicated to course offerings delivered exclusively through distance education (e.g., University of Phoenix). Almost all universities provide distance education delivery for selected courses, and the trend appears to be toward increasing the percentage of curricula available online. In addition to traditional correspondence courses and course lectures offered via the Public Broadcasting System, there are three newer technology-based methods of distance education course delivery.

First, many universities sponsor local sites for course offerings managed by intranet software (e.g., BlackBoard or WebCT). This provides an online environment for each student to submit questions, obtain responses (from the instructor or other students), obtain course documents (such as course syllabi, presentation software files, spreadsheet files, data management files, special readings documents, etc.), hold chat sessions with other students, obtain course assignments, submit completed assignments, and check grade status. The

\footnotetext{
${ }^{1}$ Lindstrom (1998) notes that PowerPoint controls over $93 \%$ of the presentation software market in the world.
} 
accompanying whiteboard software also provides the ability for students and faculty to simultaneously write on the same electronic document. This type of online visual aid supports virtual class meetings held online. Whiteboard software only offers practical support of spontaneous student written replies (i.e., a Socratic environment) if each student is equipped with an electronic writing tablet.

Second, textbook publishers provide similar homepages for each specific textbook offering. These Internet sites provide the same services and offerings as intranet pages, except the publisher provided homepages are national or international in scope, and students nationwide will not all be covering the same chapters at the same time.

A third method of offering courses via distance education is through video conferencing (i.e., compressed video). Compressed video conferencing software (e.g., PictureTel, PolyCom, Net Meeting, etc.) enables students to attend a local physical classroom and receive and interact with an instructor at a remote location through two-way video and audio hardware and software. One deterrent to this mode of distance education is the relatively high cost of offering courses in this manner, which include the usage cost of the communications lines, remote classrooms, and compressed video equipment at all classroom sites.

Results for distance education activity in accounting instruction are displayed in Table 4. These results may reflect faculty who are offering part or all of their coursework online, as well as those who use the software as a supplement to traditional classroom delivery. More than 59percent of these accounting faculty respondents do not engage in distance education through their local intranet, and only 17.2 percent of the faculty use this media for supporting more than $40 \%$ of the class meetings. Less than 10 percent of the faculty who use this media for almost all of the class meetings likely reflects instruction of purely online courses.

Slightly more than 45 percent of accounting faculty employed Internet-based software for course instruction, with 32.4 percent used the Internet for 20 percent or less of their class meetings. The greater popularity of publisher-based textbook Internet sites may be attributed to several factors. The sites come already tailor-made for the specific textbook, when enhances the ease of their use. Such sites may also offer downloadable authorprepared computer presentation slides and online study quizzes, in addition to the types of materials available with more generic intranet-based homepages.

Video conferencing is apparently rarely practiced in the delivery of accounting courses, with only 5.2 percent of the faculty using this mode of course delivery, and only 2 percent used it for more than 20 percent of the class meetings. Again, the relatively high cost may inhibit this method of course delivery.

Table 4: Distance Education Delivery

\begin{tabular}{|c|c|c|c|c|c|c|}
\hline $\begin{array}{l}\text { Delivery Method } \\
(\mathrm{n}=\mathbf{2 6 1})\end{array}$ & $\begin{array}{c}0 \% \text { of } \\
\text { the time }\end{array}$ & $\begin{array}{l}1-20 \% \text { of } \\
\text { the time }\end{array}$ & $\begin{array}{l}21-40 \% \text { of } \\
\text { the time }\end{array}$ & $\begin{array}{l}41-60 \% \text { of } \\
\text { the time }\end{array}$ & $\begin{array}{l}61-80 \% \text { of } \\
\text { the time }\end{array}$ & $\begin{array}{c}\text { more than } 80 \% \\
\text { of the time }\end{array}$ \\
\hline $\begin{array}{l}\text { Distance } \\
\text { Education } \\
\text { Software- } \\
\text { Intranet }\end{array}$ & $59.1 \%$ & $23.7 \%$ & $6.2 \%$ & $2.0 \%$ & $3.5 \%$ & $5.5 \%$ \\
\hline $\begin{array}{l}\text { Distance } \\
\text { Education } \\
\text { Software- } \\
\text { Internet } \\
\end{array}$ & $54.3 \%$ & $32.4 \%$ & $4.7 \%$ & $3.1 \%$ & $2.0 \%$ & $3.5 \%$ \\
\hline $\begin{array}{l}\text { Distance } \\
\text { Education } \\
\text { Software- } \\
\text { Video } \\
\text { Conferencing }\end{array}$ & $94.8 \%$ & $3.2 \%$ & $1.6 \%$ & $0.4 \%$ & $0.0 \%$ & $0.0 \%$ \\
\hline
\end{tabular}


A breakdown of the number of accounting courses delivered via distance education is displayed in the second part of Table 5. Only 14.9 percent of the respondents taught any courses in a distance education environment. About 7.2 percent of the respondents taught one distance learning class, and less than 8 percent conducted accounting instruction via distance education for more than one class. The questionnaire, however, did not obtain fractional course information concerning distance education. For example, some courses are offered on a $50 / 50$ basis (i.e., $50 \%$ online and $50 \%$ in a traditional classroom mode). Consequently, it is possible that some of the above participation percentages may reflect fractional online course activity.

Table 5: Number of Distance Education Courses Taught

\begin{tabular}{cc}
\hline $\begin{array}{c}\text { Number of } \\
\text { Courses }(\mathbf{n = 2 6 1})\end{array}$ & \% \\
\hline 0 & $85.1 \%$ \\
1 & $7.3 \%$ \\
2 & $5.0 \%$ \\
3 & $1.5 \%$ \\
4 & $1.1 \%$ \\
\hline
\end{tabular}

\section{Conclusions}

The use of technology to facilitate accounting instruction has increased in importance in business schools. Our results indicate that the overhead transparency projector is the most commonly used classroom hardware device with the highest rate of use in accounting classroom while the usage of VCR, digital camera and camcorder remain low. There also is an extensive use of frontoriented computer image projection in accounting education, but a relatively low percentage of faculty indicate usage of more expensive rear-oriented systems with digital chalkboard capabilities or digital image capture systems. With networked computer labs becoming a standard feature within colleges of business, less than half of the respondents indicate the use of computer labs for accounting instruction. This could be due to the nature of most accounting courses which do not require instruction to be conducted in a networked computer lab setting. In terms of software usage, our results indicate that both presentation software and spreadsheet software are widely used in accounting classrooms to various degrees. This is not a surprising result given the quantitative nature of most of the accounting courses and the relevancy of spreadsheet analysis to accounting. However, database management software (e.g., Access) usage in accounting classroom remains relatively scarce because the only accounting course that may require utilization of such software is accounting information systems.

Other than reporting the results of hardware and software usage in accounting classrooms, we also reported a profile of distance education activity in accounting. Among the three primary methods of distance education delivery methods, intranet, internet and videoconferencing, the most popular method is internet-based software followed by the use of intranet. Video conferencing is rarely used in the delivery of accounting courses, which may be due to the relatively high cost associated with this form of course delivery. We also found that the number of accounting courses delivered via distance education is still relatively low (14.9\%) with the caveat that we did not obtain information on courses that are partially online.

In general, our results indicate that accounting classroom instruction has changed from the pure "calk and talk" to the incorporation of a mixture of available hardware, software and distance learning education technology. As the costs of new classroom technology continues to decline, the opportunity for accounting faculty to incorporate new technology in their teaching pedagogy also will continue to grow. We also anticipate that technology will play an even more significant role in accounting instruction once the CPA exam is changed from paper and pencil based to a computerized exam. The changes in the CPA exam reflect the demands on today's accountants by the business world to have not only the technical accounting knowledge but also the ability to research, analyze and communicate. Our results establish a profile of technology usage pattern in today's accounting classroom that will be helpful to establish a trend of change in the role of technology in accounting education.

\section{References}

1. Agarwar, R. and Day, A. E. "The Impact of the Internet on Economic Education," Journal of Economic Education, (Spring 1998), 99-110.

2. Alreck, P., and Settle, R.B. The Survey Handbook, Homewood, IL: Richard D. Irwin, 1985. 
3. Basile, A. and D'Aquila, J.M., “An Experimental Analysis of Computer-Mediated Instruction and Student Attitudes in a Principles of Financial Accounting Course", Journal of Education for Business (Jan/Feb2002), Vol. 77, Issue 3, p137-142.

4. Becker, W. and Watts, M. "Teaching Economics: What Was, Is and Could Be." Teaching Economics to Undergraduates: Alternative to Chalk and Talk (Northampton, MA, Elgar Press, 1998), pp. 1-10.

5. Celsi, Richard, and Wolfinbarger, Mary, "Discontinuous classroom innovation: Waves of change for marketing education," Journal of Marketing Education, 24 (April 2002), 64-72.

6. Cuban, L., Oversold and Underused: Computers in the Classroom, (Harvard University Press: Boston, Mass), 2001.

7. Cudd, Mike, Lipscomb, Thomas, and Tanner, John, "Technology in the Classroom: An Assessment of Hardware and Software Usage in Finance Instruction," Journal of Education for Business (forthcoming).

8. Hagen, A., Edwards, K., and Brown, A. "The Impact of Technology on Classroom Presentations: An Empirical Investigation," The Journal of Private Enterprise, (Spring 1997), 54-68.

9. Hall, B., Web-Based Training (John Wiley \& Sons, New York, NY), 1997.

10. Hein, Scott E., and Stalcup, Katherine Austin, "Using World Wide Web Utilities to Engage Students in Money, Banking, and Credit," Journal of Education for Business, Jan./Feb. 2001, Vol. 76, Issue 3, pp. 167-172.

11. International Federation of Accountants (IFAC) Education Committee, "information Technology in the Accounting Curriculum", IEG 11, June 1998.

12. Karakaya, Fahri, Ainscough, Thomas, and Chopoorian, John, "The effects of class size and learning style on student performance in multimedia-based marketing course," Journal of Marketing Education, 23 (August 2001), $84-90$.

13. Klinger, C. and Siegel, T. "Computer Multimedia Presentations," The CPA Journal, (June 1996), 46-49.

14. Leuthold, J. "Building a Homepage for your Economics Class," Journal of Economic Education, (Summer 1998), 247-61.

15. Leydon, Betty, “The E-everything revolution: What's a university to do?” Educause Review, 36 (Jan/Feb 2001), 62-63.

16. Lindstrom, R. "Presentation Intelligence," Sales and Marketing Management, (October 1998),1-11.

17. Liu, D. and Beamer, L. "Multimedia as a Teaching Tool in Business Communication Course Delivery," Business Communication Quarterly, (June 1997), 51-66.

18. Manning, J. "Economics on the Internet: Electronic Mail in the Classroom," Journal of Economic Education, (Summer 1996), 201-204.

19. Navarro, P. and Shoemaker, J. "Performance and Perceptions of Distance Learners in Cyberspace," The American Journal of Distance Education, 2000a, 15-35.

20. Ragan, T., M., Boyce, D. R., Savenye, W and McMichael J., "Is multimedia worth it?: A review of the effectiveness of individualized multimedia instruction", Proceedings of the Association for Educational Communications and Technology Convention, 1993, New Orleans, LA.

21. Rankin, Elizabeth, and Hoaas, David, "Teaching note: Does the use of computer-generated slide presentations in the classroom affect student performance and interest?” Eastern Economic Journal, 27 (Summer 2001), 355-366.

22. Rowley, T. H. and Layne, B. H., "Evaluation of CBI in Accounting Education", Proceeding of the International Conference of the Association for the Development of Computer-based Instructional Systems (32nd), 1990, San Diego, CA.

23. Schwartz, D. L., Brophy, S, Lin X. and Bransford, J. D., "Software for managing complex learning: Examples from an educational psychology course", 1999, Educational Technology Research and Development 47 (2): 3959.

24. Smith, Lois, "Content and delivery: A comparison and contrast of electronic and traditional MBA marketing planning courses," Journal of Marketing Education, 23 (April 2001), 35-44.

25. Soloway, Elliot, "Teachers and technology: Easing the way," Association for Computing Machinery. Communications of the ACM; New York, 43 (June 2000), 23-24.

26. Spinelli, Michael A, "The Use of Technology in Teaching Business Statistics," Journal of Education for Business, (Sept./Oct. 2001), Vol. 77, Issue 1, pp. 41-44.

27. Zhoa, Yong, Pugh, Kevin, Sheldon, Stephen, and Byers, Joe, "Conditions for classroom technology innovations," Teachers College Record, 104 (April 2002), 482-515.

28. Williams, Doyle Z, Journal of Accountancy, (Aug 1993). Vol. 176, Issue 2, pp.76-82. 